\title{
DEGREE OF CONCENTRATION OF PIG PRODUCTION IN THE CONTEXT OF TRADING ON THE FOOD PLATFORM*
}

\author{
DANUTA ZAWADZKA
}

\begin{abstract}
In Poland, a characteristic feature of live pig production is its dispersion. The purpose of the article is to present the current level of concentration of pig producers and pig population, as well as structural changes that have taken place after Poland's accession to the European Union. The reference point for the degree of concentration in Poland is the degree of concentration of producers and livestock numbers in countries such as Denmark or Germany. These countries were included in the production and export of pigs and pig meat due to their position. The analysis confirms that despite the progress in concentration, both the structure of producers and the population are still fragmented.

In 2018, the Ministry of Agriculture and Rural Development took the initiative to create an electronic sales platform under the name "Food Platform". One of the goals of its establishment is to strengthen the position of farmers, who are the weakest link in the supply chain. The point is that trading on the Food Platform would bring benefits not only to large companies, but also to small entities that face difficulties to operating independently on the market. One of the products recommended for trade on the Food Platform is red meat (pork and beef) and products from this meat (Szczepaniak, Ambroziak and Drożdz, 2019). Although trade in pork half-carcases is foreseen further (wheat is to be the pilot product) and in addition will be based on transactions between slaughterhouses
\end{abstract}

\footnotetext{
*The study uses the research results of the project entitled "Food Platform" (acronym: SELLFOOD) financed by the National Centre for Research and Development under the programme "Social and economic development of Poland in the conditions of globalizing markets GOSPOSTRATEG" based on agreement no. Gospostrateg 1/385521/2/NCBR/2018.
}

Danuta Zawadzka, PhD, Institute of Agricultural and Food Economics - National Research Institute, Department of Agricultural Markets and Quantitative Methods; ul. Świętokrzyska 20, 00-002 Warsaw, Poland (Zawadzka@ierigz.waw.pl). ORCID iD: 0000-0003-4762-9888. 
and processing plants, the fragmentation of production in question will have an impact on this turnover. The turnover on the platform, in turn, may affect the position of farmers. The trade may require joint (group) action of producers, and perhaps also the proper organization of the trade on the part of the platform.

Keywords: Food Platform, pig population, farm with pigs, scale and concentration.

JEL codes: D40, O12, O13, Q13.

\section{Introduction}

The production of live pigs in Poland is one of the most important sectors of agricultural production. In 2018, its value accounted for $11.0 \%$ of the global production value and $13.6 \%$ of the commodity value of agricultural production (unpublished GUS data, 2019). It was the fourth product (after milk, cereals and poultry). The market of live pigs is the second largest market of meat (after the market of poultry meat). In 2018, the total domestic production of pork and pork fats was 1,973 thousand tonnes in hot carcass weight, accounting for $38.0 \%$ of the total production of animal meat and fats (including poultry).

In recent years, the market of live pigs has lost its leading position in the production of meat for poultry, but pork is still dominant in the consumption of meat. The share of pork in the total consumption in 2018 was $52.3 \%$, while that of poultry meat amounted to $35.3 \%$. This consumption structure is supported by population preferences and relatively high import of pork products which is related to these preferences. Poland is a net importer of live pigs, pork and pork products. In 2018, the negative balance of trade in pork products amounted to 171 thousand tonnes, with the export of 818 thousand tonnes and the import of 989 thousand tonnes. The major markets for selling Polish pork are the European Union countries, but not only. Poland is a relatively large exporter of pork products to third countries. In 2018, Poland was ranked fifth among the EU-28 countries in terms of the export volume of pork products to third countries (after Germany, Spain, Denmark and the Netherlands).

The importance of pork in the production, export and consumption of meat is a reason for which we may expect a great interest in this product in turnover on the Food Platform. However, the market position of pork may be weakened by the dispersion of supply, which starts in the basic link of the supply chain, i.e. at the level of producers. Dispersion is a characteristic feature of pig rearing in Poland, despite progress made in this regard, which has been taking place for many years. This progress takes place mainly at the expense of the smallest farms, due to the gradual increase in production costs which limits small-scale rearing. The increase in production costs is expressed by the two simplest ratios expressing the profitability of rearing, i.e. the ratio of the prices of pigs to the marketplace prices of cereals and feed, and the ratio of marketplace prices of piglets to the prices of live pigs. These ratios indicate that pig prices are going down on a long-term 
basis in relation to cereals and feed while piglets prices are going up in relation to live pigs. Both ratios are responsible for a long-term downward trend in the pig population (Zawadzka, 2016; 2017). As a result, in the years 2005-2016, 75.0\% of pig farms resigned from pig rearing. The decrease in the number of pig farms was much higher than that in the total number of farms (48.4\%).

A similar phenomenon takes place in the European Union countries, including Denmark and Germany. In these countries, the high level of concentration was also caused by factors determining the production economics of farms rearing pigs. In both countries, the decrease in the number of these farms was higher than the decrease in the number of all farms. In Denmark, in the years 2012-2018, the total number of farms decreased from 39.9 to 34.1 thousand, i.e. by $14.5 \%$. The reduction in the number of farms involved in pig rearing was deeper, standing at $25.3 \%$ (the number of those farms decreased from 4,181 to 3,125 ). There was a similar situation in Germany. In the years 2013-2018, the number of all farms decreased from 285 to 266.7 thousand, i.e. by $6.4 \%$. In this period, the number of farms keeping pigs decreased from 27.9 to 22.4 thousand, i.e. by $19.7 \%$. A larger decrease in the number of farms rearing pigs than in the total number of farms means that this phenomenon resulted not only from general structural changes, but also from the impact of additional factors affecting this production on the market.

\section{Structure of farms involved in pig rearing in Poland and structure of pig population depending on the scale of rearing}

In June 2016, in Poland there were 157 thousand farms involved in pig rearing. The largest group were small farms, i.e. keeping 1-49 head. Their share in the total number of farms was $79.2 \%$. Farms keeping from 50 to 199 head accounted for $15.8 \%$ of farms with pigs and farms with more than 200 head $-5.0 \%$, including farms with 1,000 head and more - less than 1\% (0.6\%) (Fig. 1).

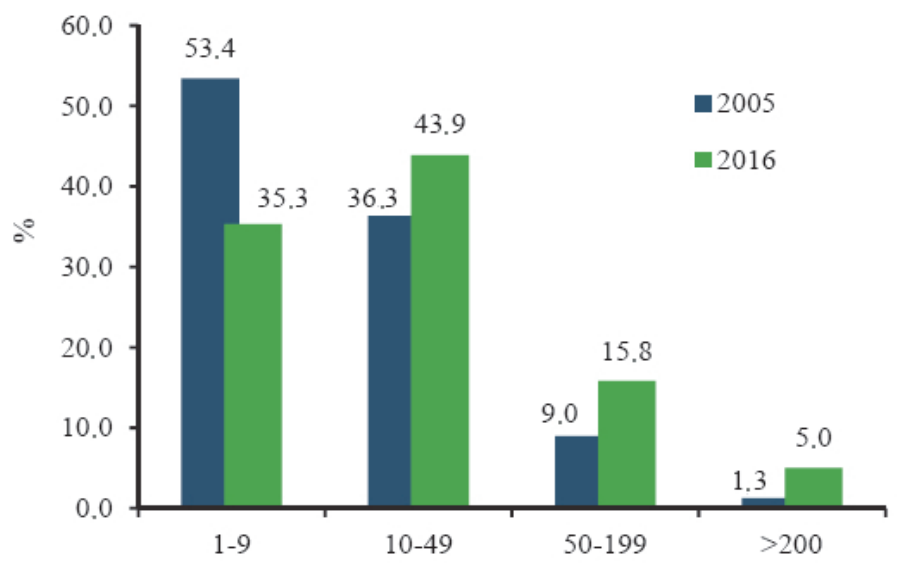

Fig. 1. Structure of pig farms in Poland by number of pigs kept.

Source: the GUS data, the IAFE-NRI calculations. 
When compared to 2005, there was an increase in the concentration of producers. The share of small farms decreased and the share of medium and large farms increased. In the years 2005-2016, the share of farms keeping 50-199 head increased from 9.0 to $15.8 \%$ and that of farms keeping more than 200 pigs from 1.3 to $5.0 \%$. In 2016 , on farms with $1-49$ head there were only $16.6 \%$ of pig population, and on farms with 50-99 head $-20.9 \%$. On the other hand, on farms with more than 200 pigs, there were $62.5 \%$ of pig population, including farms with more than 1,000 head $-37.5 \%$ of pig population and on farms with more than 5,000 head $25.0 \%$ of pig population (Fig. 2).

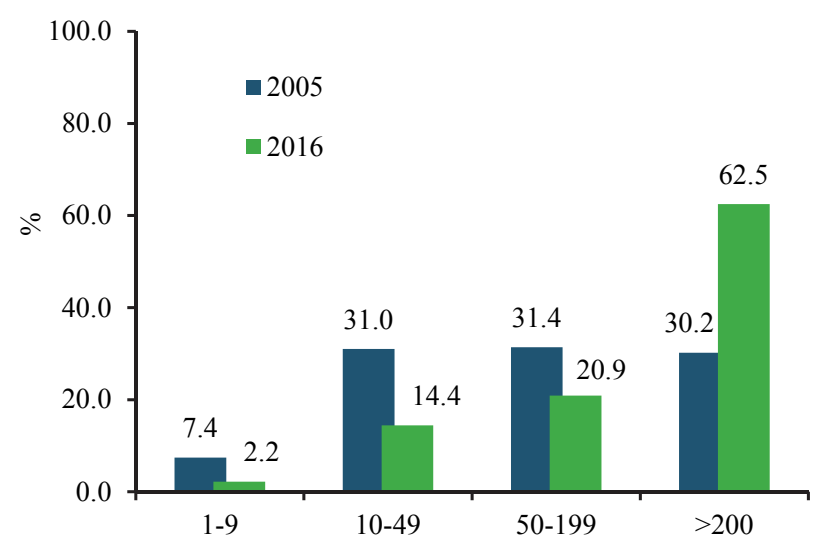

Fig. 2. Structure of pig population in Poland by number of pigs kept.

Source: the GUS data, the IAFE-NRI calculations.

Progress in the concentration of pig population was much greater than in the concentration of farms, although the increase in the share of pig population was recorded only on farms keeping more than 200 pigs (from 30.2 to $62.5 \%$ ). The increase in the pig population on farms rearing more than 200 head means that this scale should be assessed as a border scale allowing to develop rearing in a situation of narrow ratios expressing the profitability of rearing.

The unpublished GUS data shows that in 2017 the number of farms with pigs decreased by $7.0 \%$ and in 2018 by another $8.0 \%$. Based on those figures, it can be concluded that in 2018 there could have been about 135 thousand farms rearing pigs. There could have been around 88 pigs per one farm with pigs (as of June). However, GUS does not provide data either on the number of farms or the structure of producers by scale of rearing.

In 2017 and 2018, as a result of the improved profitability due to the rise in the prices of pigs, the pig population increased when compared to 2016 by $4.5 \%$ (in June 2017 when compared to June 2016) and by 4.2\% (in June 2018 when compared to June 2017). The high level of prices of swine and the improved profitability of rearing usually weaken the concentration processes, while the low level of prices 
and deteriorated profitability of rearing strengthen them (Małkowski and Zawadzka, 2000). Despite the relatively good situation in rearing, the above-mentioned years saw further progress in the population concentration. As in previous periods, it occurred as a result of the decreased pig population on all farms with herds smaller than 200 head. The reason for the reduced pig population on small farms could be additional ASF- and biosecurity-related costs. As a result, in 2018 on farms with 1-9 head there were $1.7 \%$ of pig population and on farms with $10-49$ head $-11.0 \%$. On farms with the scale of rearing of 50-199, there were $17.9 \%$ of pig population and on those with the scale of more than 200 pigs $-69.4 \%$ of pig population, including farms with the scale of rearing of more than 1,000 head $-44.5 \%$ of pig population and on farms with more than 5,000 head $-26.0 \%$ of pig population.

In June 2019, there was an annual decrease in the pig population (by $8.9 \%$ when compared to June 2018). This resulted from the low prices of swine in 2018 (in 2018, the average annual buying-in price of swine was by $12.0 \%$ lower than in 2017). This resulted in a reduction of ratios expressing the profitability of rearing by $17.0 \%$ (the ratio of buying-in prices of live pigs to marketplace prices of rye) and by $17.6 \%$ (the ratio of buying-in prices of live pigs to marketplace prices of barley). The deteriorated profitability of rearing led to another reduction in the population on small farms. The share of pig population increased on farms with more than 200 pigs, which resulted probably from the will to achieve additional economies of scale or to maintain the level of previously obtained income on these farms.

In 2019, on farms with 1-49 head, there were $1.2 \%$ of pig population, and on farms with 50-99 head $-15,3 \%$. On the other hand, on farms with the scale of rearing of more than 200 pigs, there were $75.0 \%$ of pig population, including farms with the scale of rearing of more than 1,000 head $-49 \%$ of pig population and on farms with more than 5,000 head $-27.0 \%$ of pig population.

As a result, in the years 2016-2019, the share of pig population on farms with more than 200 pigs increased by 12.5 p.p. with the decrease in the total pig population in those years by $0.8 \%$. The share of herds with the highest population (more than 5,000 head) increased by 3 p.p. The increase in the share of pig population on farms with herds larger than 200 head was at the expense of the decreased share of pig population on small and particularly medium farms. The share of pig population on the smallest farms decreased by 1 p.p., but on farms with 10-49 pigs by 5.9 p.p. and on farms with $50-199$ pigs - by 5.6 p.p.

From the point of view of future turnover on the Food Platform, the regional distribution of concentration of rearing is also important. The largest percentage of pig population in herds larger than 1,000 animals is characteristic of the following voivodeships: Zachodniopomorskie (83\%), Lubuskie (77\%), Dolnośląskie (71\%), Pomorskie (64\%) and Wielkopolskie (50\%) (Fig. 3). 


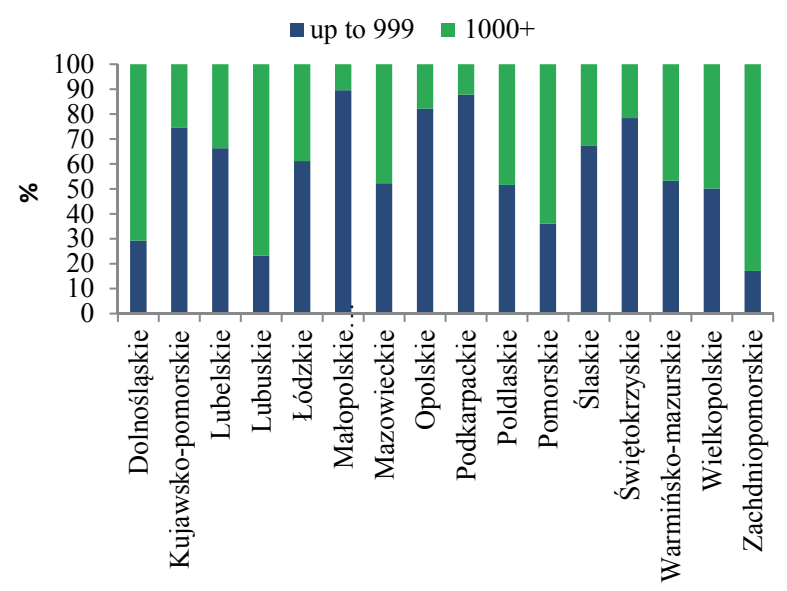

Fig. 3. The share of pig population in herds smaller and larger than 1,000 animals (by voivodeship). Source: the GUS data, the IAFE-NRI calculations.

These voivodeships can be relatively large participants in trade on the Food Platform, although for most of them (apart from the Wielkopolskie Voivodeship), the share in the nationwide pig population is within the range of $1-7 \%$. The largest share in the national pig population is that of the Wielkopolskie Voivodeship (36.3\%), but attention should also be paid to the Lódzkie and Mazowieckie Voivodeships, where the share of pig population in the national pig population is 10.4 and $10.3 \%$, respectively, while the percentage of pig population in herds larger than 1,000 head amounts to 39.8 and $56.7 \%$, respectively.

\section{Structure of pig farms in Denmark and Germany and structure of pig population by scale of rearing}

Despite the positive changes, pig rearing in Poland is still fragmented, especially with regard to the European Union countries such as Denmark and Germany, which are large producers and exporters of swine. When compared to these countries, definitely the largest number of pig-keeping farms is present in Poland. In Denmark, which is ranked fourth in the EU-28, in terms of pig population, in 2018 there were 3.1 thousand farms involved in pig rearing, i.e. only about $2 \%$ of the number of Polish farms involved in pig rearing, with the pig population by about $15 \%$ higher than in Poland (as of June). In Germany, in May 2018 there were 22.9 thousand farms involved in pig rearing, i.e. about $17 \%$ of the number of farms with swine in Poland, with the pig population more than doubled.

In the years 2006-2016, progress was made with respect to concentration in Denmark as a result of reduction in the number of farms, accompanied by minor changes in the pig population. At that time, the number of pig farms decreased by $58.0 \%$ and in the following two years (2016-2018) by further 5.1\%. The pig population, which decreased by $2.3 \%$ in the years $2006-2016$, increased by $4.6 \%$ in the years 2016 -2018. As a consequence, the pig population per one farm increased in the years 2006-2016 from 1,709 to 3,856 head and to 4,090 head in 2018. 


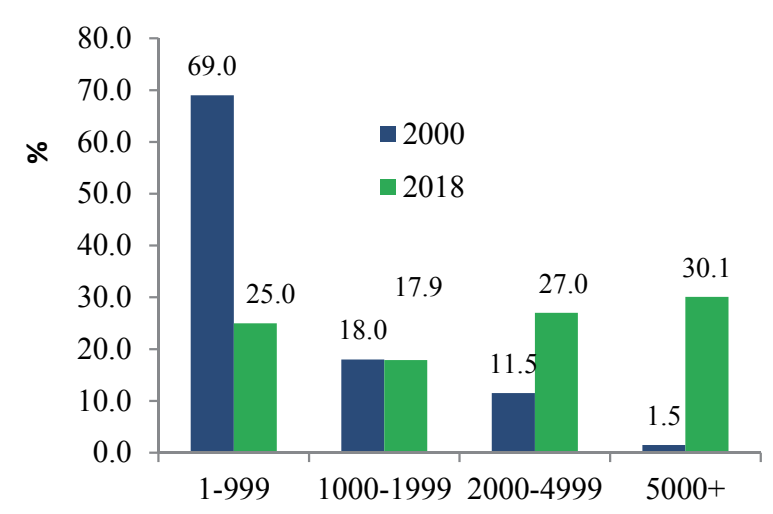

Fig. 4. Structure of pig-keeping farms in Denmark by number of pigs kept. Source: the Danmarks Statistik data, the IAFE-NRI calculations.

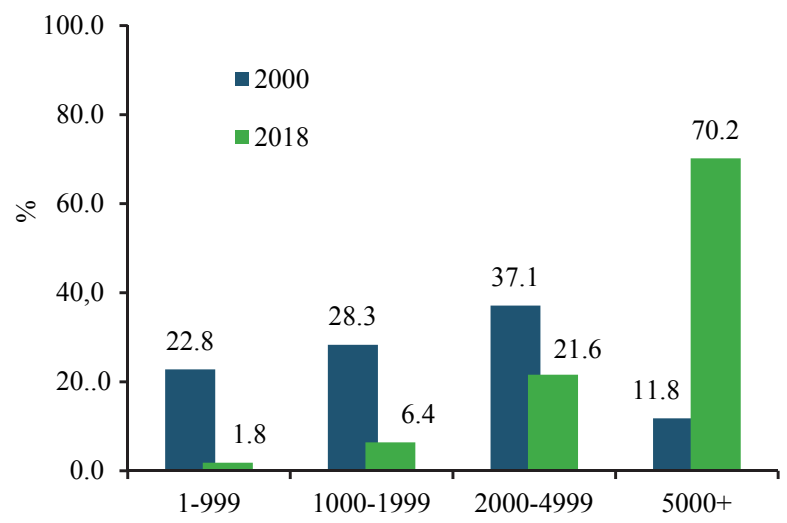

Fig. 5. Structure of pig population in Denmark by number of pigs kept.

Source: the Danmarks Statistik data, the IAFE-NRI calculations.

The high average pig population per one farm stems from the very high production by relatively few producers. In 2000, the share of farms with the scale of rearing of up to 1,000 pigs was dominant in the structure $(69.0 \%)$, but for the pig population the share of those farms was $22.8 \%$ (Figs. 4 and 5). Farms with herds from 2,000 to 4,999 pigs had the largest share of the pig population $(37.1 \%)$, but their share in the number of farms was small and stood at $11.5 \%$. In 2018 , only $25.0 \%$ of farms among farms with pigs were involved in rearing on the scale below 1,000 head, and $17.9 \%$ of farms - on the scale between 1,000 and 1,999 head. However, the share of those farms in the total pig population was 1.8 and $6.4 \%$, respectively. Meanwhile, $47.1 \%$ of farms had pigs in herds of more than 2,000 animals, including $30.1 \%$ in herds of more than 5,000 head. The share of those farms in the total pig population was 91.8 and $70.2 \%$, respectively. The smallest 
group was that of the largest producers, i.e. with the scale of rearing of more than 25,000 head. In 2018, farms with this scale of rearing accounted for less than $0.5 \%$ of farms with pigs, but they had about $4 \%$ of pig population, with the average pig population per one farm amounting to 35,816 head.

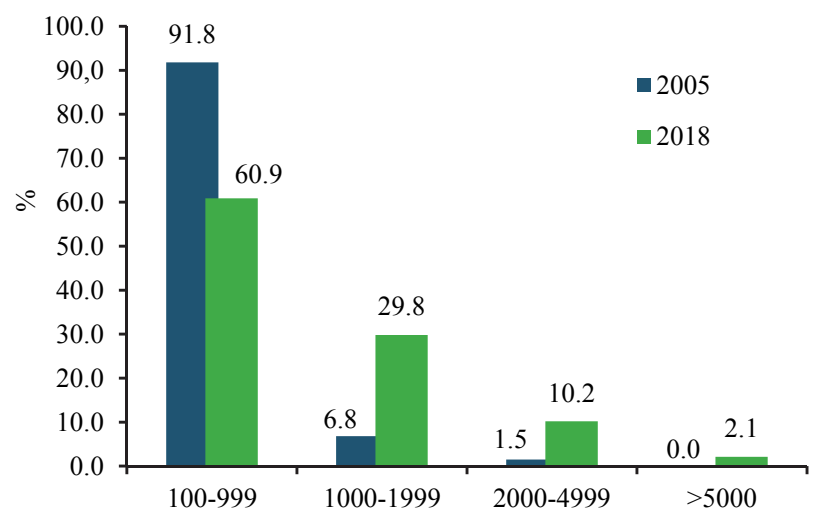

Fig. 6. Structure of pig-keeping farms in Germany by number of pigs kept.

Source: the Destatis data, the IAFE-NRI calculations.

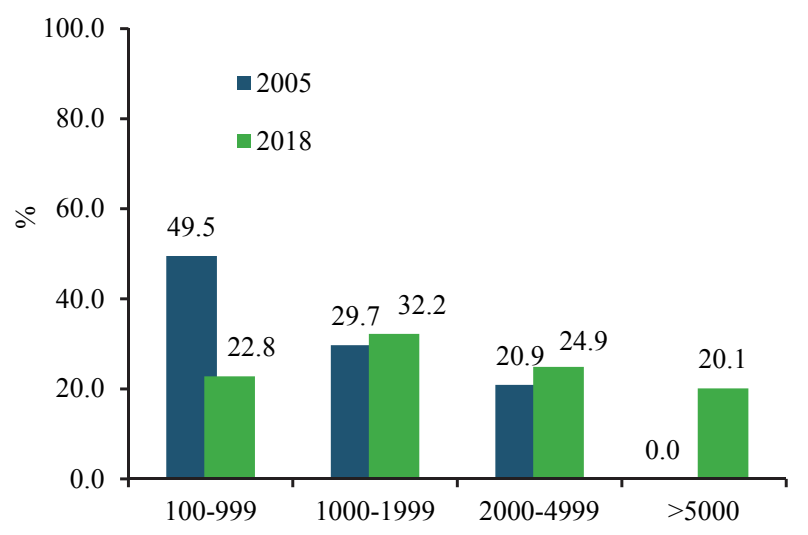

Fig. 7. Structure of pig population in Germany by number of pigs kept.

Source: the Destatis data, the IAFE-NRI calculations.

In Germany, in 2018, there were 1,175 pigs per one farm, which is significantly less than in Denmark, but many times more than in Poland. Just like in Denmark, this results from the production concentration on relatively large-scale farms. In 2018, among pig-keeping farms, $60.9 \%$ had pigs in herds of up to 1,000 animals. The remaining $39.1 \%$ of farms kept the pig in herds larger than 1,000 head, including 2.1\% in herds larger than 5,000 head (Fig. 6). In 2005, farms with fewer than 1,000 head accounted for $91.8 \%$ of all pig farms and farms with more than 
1,000 head - the remaining $8.2 \%$. In 2018, the population on farms with fewer than 1,000 head accounted for $22.8 \%$ of pig population, while $77.2 \%$ of pig population were on farms with the scale of more than 1,000 head, including $20.1 \%$ of population on farms with the scale of more than 5,000 head (Fig. 7). In the years 2000-2018, the reduction in the population on farms with fewer than 1,000 pigs was 27 p.p. The share of farms with more than 1,000 pigs increased by the same percentage. The largest beneficiary of reduction in the pig population on small farms were farms with the scale of rearing of more than 5,000 head (20 p.p.).

Table 1

Structure of pig population (by scale of rearing) in Poland, Germany and Denmark in $2018(\%)$

\begin{tabular}{cccc}
\hline Scale of rearing & Poland & Germany & Denmark \\
\hline Up to 999 head & 55.4 & 22.8 & 2.5 \\
$1,000-1,999$ & 10.9 & 32.2 & 6.6 \\
$2,000-4,999$ & 7.6 & 24.9 & 27.3 \\
More than 5,000 & 26.1 & 20.1 & 63.6 \\
\hline
\end{tabular}

Source: Own calculations based on the GUS, Destatis and Danmarks Statistik data.

If we change the ranges of scale of rearing, adapting them accordingly to German or Danish ranges, it is clear that in Poland, when compared to Germany, the share of pigs kept in herds of more than 5,000 head is higher (Table 1), but at the same time many more pigs are kept in herds of up to 999 head. On the other hand, the share of population in herds of 1,000-1,999 head and of 2,000-4,999 head is relatively small. It is noteworthy that in Germany all these groups have the similar share of the population structure, so their importance in production is similar. This is all the more important that, in terms of profitability of production, the scale of production of pigs in Poland should increase (Mirkowska and Ziętara, 2019). It would be good if the increase in the scale of production applied to groups with 1,000-1,999 pigs and 2,000-4,999 pigs, rather than the largest farms, i.e. those with more than 5,000 animals. This is relevant from the point of view of environmental protection and sustainable production, greening of the common agricultural policy or the ecological type of production development.

The Food Platform can strengthen the bargaining position of relatively small producers. According to Figiel (2019), the large fragmentation of the food supply chain strengthens expectations regarding the development of e-commerce. In such situation, in order to support small farms in eliminating inefficiencies and barriers to market access, Figiel (2019) proposes two main approaches. The first concerns collective measures by establishing farmers' organisations due to which small producers will be much more empowered in negotiations with buyers. The second approach consists in promoting the conclusion of agreements between small farms and agribusiness com- 
panies. In the case of pork producers, this means relations to slaughterhouses or meat processing plants. The latter case is particularly important, as pork half-carcasses will be traded in the first phase of trade in pork products. It also seems that fulfilling the hopes placed in trade on the platform may require the platform to take on the role of market regulator or coordinator at least at the early stage.

\section{Summary}

The analysis of structure of producers and pig population allows to conclude that despite progress in concentration, rearing is still strongly fragmented. This is particularly evident when compared to the high concentration of rearing in countries such as Germany and Denmark. In Poland, when compared to these countries, the highest percentage of pigs is on farms with fewer than 1,000 head, however, the percentage of pig population kept on farms with more than 5,000 head is higher than in Germany.

From the point of view of selling on the Food Platform, this structure is not beneficial as it results in the fragmentation of supply. It is expected that the Food Platform will improve the position of producers. However, for this to happen, farmers will have to establish groups or otherwise organise themselves so as to become empowered in trade with slaughterhouses and meat processing plants. At the same time, the Food Platform should take on the role of market regulator or coordinator at least in the initial period. 


\section{References}

Figiel, S. (2019). Rynki rolne $i \dot{z y}$ wnościowe $w$ dobie innowacji cyfrowych. Studia i Monografie, No. 176. Warszawa: IERiGŻ-PIB.

GUS (2006). Charakterystyka gospodarstw rolnych w 2005 r. Warszawa: GUS.

GUS (2008). Charakterystyka gospodarstw rolnych w 2007 r. Warszawa: GUS.

GUS (2012). Charakterystyka gospodarstw rolnych w 2010 r. Powszechny Spis Rolny. Warszawa: GUS.

GUS (2014). Charakterystyka gospodarstw rolnych w 2013 r. Informacje i Opracowania Statystyczne. Warszawa: GUS.

GUS (2017). Charakterystyka gospodarstw rolnych w 2016 r. Informacje i Opracowania Statystyczne. Warszawa: GUS.

GUS (2006-2018). Rocznik Statystyczny Rolnictwa 2005-2017. Warszawa: GUS.

GUS (2008). Rocznik Statystyczny Rolnictwa i Obszarów Wiejskich 2008. Warszawa: GUS.

GUS (2017). Rocznik Statystyczny Rzeczypospolitej Polskiej 2017. Warszawa: GUS.

Danmarks Statistik. Retrieved from: www.statistikbanken.dk.

Destatis, Statistisches Bundesamt, Fachserie 3, Reihe 4.1. Mai 2018.

Małkowski, J., Zawadzka, D. (2000). Rynek mięsa wieprzowego. In: E. Majewski, G. Dalton (ed.), Strategiczne opcje dla polskiego sektora agrobiznesu w świetle analiz ekonomicznych. Warszawa: SGGW, Centrum Naukowo-Wdrożeniowe.

Mirkowska, Z., Ziętara, W. (2019). Pozycja konkurencyjna polskich gospodarstw trzodowych nastawionych na chów trzody chlewnej. Zagadnienia Ekonomiki Rolnej, No. 1(358), p. 44-63. DOI: $10.30858 /$ zer/103751.

Szczepaniak, I., Ambroziak, Ł., Drożdż, J. (2019). Identyfikacja grup produktów rekomendowanych do wymiany handlowej na Platformie Żywnościowej w świetle obrotów krajowych i zagranicznych. Zagadnienia Ekonomiki Rolnej, No. 4(361), p. 82-105. DOI: 10.30858/zer/115187.

Szymańska, E. (2012). Produkcja żywca wieprzowego w zrównoważonym rozwoju rolnictwa Zagadnienia Ekonomiki Rolnej, No. 3(332), p. 89-103.

Zawadzka, D. (2018). Chów trzody w gospodarstwach industrialnych i konwencjonalnych. A paper presented during the international conference entitled "Gospodarstwa industrialne versus drobnotowarowe - konkurenci czy partnerzy? (Industrial versus small farms - competitors or partners?)" organised by IAFE-NRI under the Multi-Annual Programme 2015-2019 "The Polish and the EU agricultures 2020+. Challenges, chances, threats, proposals". Jachranka 10-12.12.2018.

Zawadzka, D. (2016). Rynek wieprzowiny. In: S. Stańko (ed.), Sytuacja na światowych rynkach mięsa i produktów mleczarskich oraz jej wpływ na rynek krajowy i możliwości jego rozwoju. Monografie Programu Wieloletniego 2015-2019, No. 31 (p. 40-78). Warszawa, IERiGŻ-PIB.

Zawadzka, D. (2017). Ryzyko produkcyjne i cenowe na rynku żywca wieprzowego In: J. Góral, M. Wigier (ed.), Ryzyko w gospodarce żywnościowej - teoria i praktyka. Monografie Programu Wieloletniego 2015-2019, No. 48 (p. 107-122). Warszawa: IERiGŻ-PIB.

Zegar, J.S. (2019). Perspektywy gospodarstw rodzinnych w Polsce. Zagadnienia Ekonomiki Rolnej, No. 3(360), p. 31-53. DOI: 10.30858/zer/111997. 


\title{
STOPIEŃ KONCENTRACJI CHOWU TRZODY W KONTEKŚCIE OBROTÓW NA PLATFORMIE ŻYWNOŚCIOWEJ
}

\begin{abstract}
Abstrakt
W Polsce charakterystyczna cecha produkcji żywca wieprzowego jest jej rozdrobnienie. Celem artykułu jest przedstawienie aktualnego stopnia koncentracji producentów trzody i pogłowia trzody, a także zmian strukturalnych $w$ tym zakresie, jakie nastapity po przystapieniu Polski do Unii Europejskiej. Punktem odniesieniem sa identyczne parametry w takich krajach, jak Dania czy Niemcy. Kraje te uwzględniono ze względu na ich pozycje w produkcji i eksporcie mięsa wieprzowego oraz jego przetworów. Przeprowadzona analiza potwierdza, ze pomimo postępu w zakresie koncentracji, zarówno struktura producentów, jak i pogtowie sa nadal rozdrobnione.

W 2018 r. Ministerstwo Rolnictwa i Rozwoju Wsi podjęto inicjatywe stworzenia elektronicznej platformy sprzedażowej pod nazwa „,Platforma Żywnościowa”. Jednym z celów jej powołania jest wzmocnienie pozycji rolników będacych najsłabszym ogniwem w tańcuchu dostaw. Chodzi o to, by handel na Platformie Żywnościowej przynosit korzyści nie tylko dużym firmom, ale także małym podmiotom, którym trudno jest działać samodzielnie na rynku. Jednym $z$ produktów rekomendowanych do wymiany handlowej na Platformie Żywnościowej jest miesso czerwone (wieprzowe $i$ wołowe) oraz produkty z tego miessa (Szczepaniak, Ambroziak i Drożdz, 2019). Wprawdzie handel póttuszami wieprzowymi przewidziany jest $w$ dalszej kolejności (produktem pilotażowym ma być pszenica) $i w$ dodatku będzie opierat się o transakcje między ubojniami a zakładami przetwórczymi, to jednak rozdrobnienie produkcji, o jakim mowa, będzie miało wpływ na te obroty. Obroty na Platformie moga z kolei mieć wptyw na pozycję rolników. Handel ten może wymagać wspólnego (grupowego) działania producentów, a być może także odpowiedniej organizacji tego handlu ze strony Platformy.
\end{abstract}

Słowa kluczowe: Platforma Żywnościowa, pogłowie trzody, skala i koncentracja chowu.

Accepted for print: 19.06 .2020 .

Unless stated otherwise all the materials on the website are available under the Creative Commons Attribution 4.0 International license.

Some rights reserved to the Institute of Agricultural and Food Economics - National Research Institute.

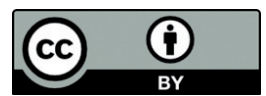

